\title{
GROWTH AND YIELD PERFORMANCE OF POTATO VARIETIES UNDER DIFFERENT PLANTING DATES
}

\author{
B. Ahmed ${ }^{1 *}$, M. Sultana ${ }^{2}$, M. A. H. Chowdhury ${ }^{3}$, S, Akhter ${ }^{4}$, and M. J. Alam ${ }^{5}$ \\ ${ }^{1}$ Plant Physiology Division, BARI, Gazipur \\ ${ }^{2}$ Tuber crop Research Sub-Center, BARI, Seujgari, Bogra \\ ${ }^{3}$ Upazila Agriculture Officer (LR), Department of Agricultural Extension \\ Khamarbari, Dhaka-1215 \\ ${ }^{4}$ Agronomy Division, BARI, Joydebpur, Gazipur \\ 5 Soil Science Division, BARI, Gazipur \\ *Corresponding Author: kbdahmed@gmail.com
}

Key words: Growth, phonological, sowing date, variety

\begin{abstract}
An experiment was conducted during 20 November 2015 through March 2016 to assess the effect of planting dates on growth and yield performance of three potential varieties of potato at Plant Physiology research field, Bangladesh Agricultural Research Institute, Gazipur. Three planting dates (November 20, December 5 and December 29) and three varieties (var. BARI Alu-35, BARI Alu-40 and BARI Alu-41) were the treatment variables. The experiment was laid out in a randomized complete block design with three replications. Maximum plant height $(42.3 \mathrm{~cm})$ was observed in 5 December sowing in var. BARI Alu-40. Highest number of tuber/plant (13) was recorded from December 5 sowing in var. BARI Alu-41. The highest leaf area was found in December 5 sowing of BARI Alu- 40 while the lowest leaf area in November 20 sowing in var. BARI Alu-35. The highest tuber weight/plant $(97.25 \mathrm{~g})$ was observed in var. BARI Alu-5 at December 5 sowing and the lowest tuber weight/plant $(25.58 \mathrm{~g})$ in var. BARI Alu-35 at November 20 sowing. The maximum potato yield (42.12 t/ha) was obtained at December 5 sowing of BARI Alu-35 followed by same date of var. BARIAlu- 41. From the experiment it was revealed that the first decade of December is the optimum date for planting of potato due to the physiological maturity and tuber yield.
\end{abstract}

\section{Introduction}

Potato is the world's fourth-largest food crop after rice, wheat, and maize (Haas et al., 2009; Chakraborty et al., 2010; Li, 1985 .This crop can be consumed as a vegetable and also as the major food item. Its yield and quality are both dependent on variety and cultural practice as well as environmental condition, including rainfall, temperature, light, and $\mathrm{CO}_{2}$ (Dalla Costa et al., 1997). Potato produces the highest amount of energy per unit area and has the highest dry matter yield which may be $74.5 \%$ compared to wheat and $58 \%$ compared to rice. Potato planting dates for each region is one of the factors that have a significant role in the performance of this product. Proper planting makes all the environmental factors occurring at the time of emergence, and seedling establishment of appropriate. Each stage of growth coincide with environmental conditions is desired. Yield difference in delayed planting dates is caused by reduction in number of tubers per plant and shrinkage of leaves. Potato planting date can be determined based on its growth season duration in any region. Delayed planting dates cause yield reduction (Peter et al., 1988). In Bangladesh, the optimum time of sowing of potato is the second week of November, but in many cases the potato crops are planted under late 
Ahmed et al.

sown condition due to delayed harvesting of transplanted aman. Plant growth at delayed planting significantly reduced the vegetable growth of the potato plant because of lower temperatures in the end of October and earlier November. Delayed planting reduced the yield of potato. Plant dry bio-mass was higher by planting the potato earlier. The physiological causes that led to yield reduction in delayed planting of potato had not been reported from Bangladesh. Therefore, an attempt was undertaken to analyze the growth, development indices of different potato varieties and yield of potato in relation to planting date.

\section{Materials and Methods}

The experiment was conducted at Plant Physiology research field, BARI, Joydebpur, Gazipur during rabi season of 2015-16. The soil was silty clay loam in texture belonging Chhiata series under AEZ-28 having low organic matter (0.97\%) and deficient in total nitrogen (0.056\%), available phosphorus (12 ppm), exchangeable potassium $(0.17 \mathrm{meq} / 100 \mathrm{~g}$ soil) and available sulpher (10 ppm). Three planting date (November 20, December 5 and December 29) and three varieties (var. BARI Alu-35, BARI Alu-40 and BARI Alu-41) were studied and laid out in randomized complete block design with three replications. The plot size was $3.6 \mathrm{~m} \times 5.4 \mathrm{~m}$. The fertilizer dose was $\mathrm{N}_{23}, \mathrm{P}_{18}$ and $\mathrm{K}_{20} \mathrm{Kg} / \mathrm{ha}$ and were applied in the form of urea, triple super phosphate (TSP) and muriate of potash (MoP), and Gypsum, respectively. One third of total fertilizers were applied as basal and two times urea fertilizer were applied as top dressed. A light irrigation was given before sowing of seeds for uniform germination. The seeds were sown with spacing of $30 \mathrm{~cm} \times 60 \mathrm{~cm}$ in the depth of $5 \mathrm{~cm}$ in furrow followed by earthing up. The plots were weeded by hand during the early growth stage and irrigated by three times including germination. Ten plants were collected from each plot at vegetative and flowering stage for leaf area measurement. The emergence and physiological maturity were taken when $70 \%$ of plants emerged and leaves of plants turned yellow, from observations at 23-days intervals. For tuber formation, four plants in each replication two or three times a week from about two weeks after emergence were dug up and were analyzed as in Kawakami et al. (2003). The yield components data were taken from 10 randomly selected plants prior to harvest from each plot. The dry weights (DW) of tuber and leaf were measured after oven drying at $70^{\circ} \mathrm{C}$ for more than $72 \mathrm{hrs}$, and the leaf area index (LAI) was calculated as the product of the measured leaf area and leaf dry weight ratio and the total leaf dry weight. The marketable (heavier than $20 \mathrm{~g}$ ) tuber fresh and dry weights were recorded after physiological maturity for 12 plants of each cultivar and tuber type in each replication. Harvesting was done at maturity stage. At harvest, the yield attributes and tuber yield was analysed as per MSTAT-C software.

\section{Result and discussion}

Sowing dates influenced vegetative (emergence to first flowering time) and reproductive growth stages (flowering to pod maturity time) of crops (Akther et al., 2013). Time of sowing also determines time of flowering and it has great influence on dry matter accumulation, seed set and seed yield (Sofield, 1977). Availability of light on potato canopy was almost 100\% at earlier growth stage of potato (Begum et al. 2015). The highest plant height $(40.9 \mathrm{~cm})$ was obtained from the December 5 sowing at BARI Alu-40 whether the lowest plant height (25.7 $\mathrm{cm}$ ) at December 20 sowing in BARI Alu-35 at 45 Days after Planting (DAP). Highest leaf area (250 $\mathrm{cm}^{2} /$ plant) was observed at December 5 sowing at BARI Alu-35 while the lowest leaf area (120 $\mathrm{cm}^{2} /$ plant) at November 20 sowing at BARI Alu-35. In case of dry matter, the 
highest (16.30) was observed at BARI Alu-35 at November 20 sowing while the lowest (9.20) at December 20 sowing at the same variety.

At 60 DAP, the highest plant height $(56.68 \mathrm{~cm})$ was observed at BARI Alu-40 at December 20 sowing where the lowest $(34.35 \mathrm{~cm})$ at BARI Alu 40 at November 20 Sowing. In case of leaf area, the highest $\left(600 \mathrm{~cm}^{2} /\right.$ plant) was obtained at BARI Alu- 40 in December 5 Sowing while the lowest leaf area (320 $\mathrm{cm}^{2} /$ plant) at December 20 sowing at BARI Alu- 41 . The highest Dry Matter (21.54 \%) was found BARI Alu- 41 at November 20 sowing while the lowest dry matter (17.34\%) at BARI Alu-40 at December 5 sowing (Table 3). Maximum plant height was observed in 5 December sowing in BARI Alu-40 $(40.9 \mathrm{~cm})$ while the lowest plant height $(25.7$ $\mathrm{cm}$ ) in the same variety (BARI Alu-40) at 20 December sowing (Table 3). Plant height of November 5 and December 20 sowing was similar and significantly lower than the other sowings. Highest number of tuber/hill (13) was recorded from December 5 sowing and higher than those of other two sowings. The highest leaf area $\left(250 \mathrm{~cm}^{2} /\right.$ plant $)$ was found in December 5 sowing of BARI Alu- 40 while the lowest leaf area $\left(136 \mathrm{~cm}^{2} /\right.$ plant $)$ in November 20 sowing in BARI Alu-35. The highest tuber weight/plant (g) were observed at BARI Alu-35 at December 5 sowing time and the lowest tuber weight/plant (g) in BARI Alu-35 at November 20 sowing. In case of potato yield, the highest potato yield (42.12 t/ha) was obtained at December 5 sowing of BARI Alu- 40 followed by BARI Alu-35 of the same sowing time. In the vegetative growth, the highest plant height, leaf area, leaf number was found in BARI Alu-41 at 45 DAP but the highest leaf area at 60 DAP in December 5 sowing at BARI Alu-35 sowing (Fig. 2). Delayed planting had adverse effect on leaf area resulting in lower total dry matter and ultimately reduced yield (Shaheenuzzamn et al., 2015). Reduced leaf growth resulted in smaller canopy and produce smaller tuber. Due to difference of plantation time there was synchronization of the internal and external clock, which affect physiological process in plants and ultimately on yield of potato (Hossain et al,. 2010).

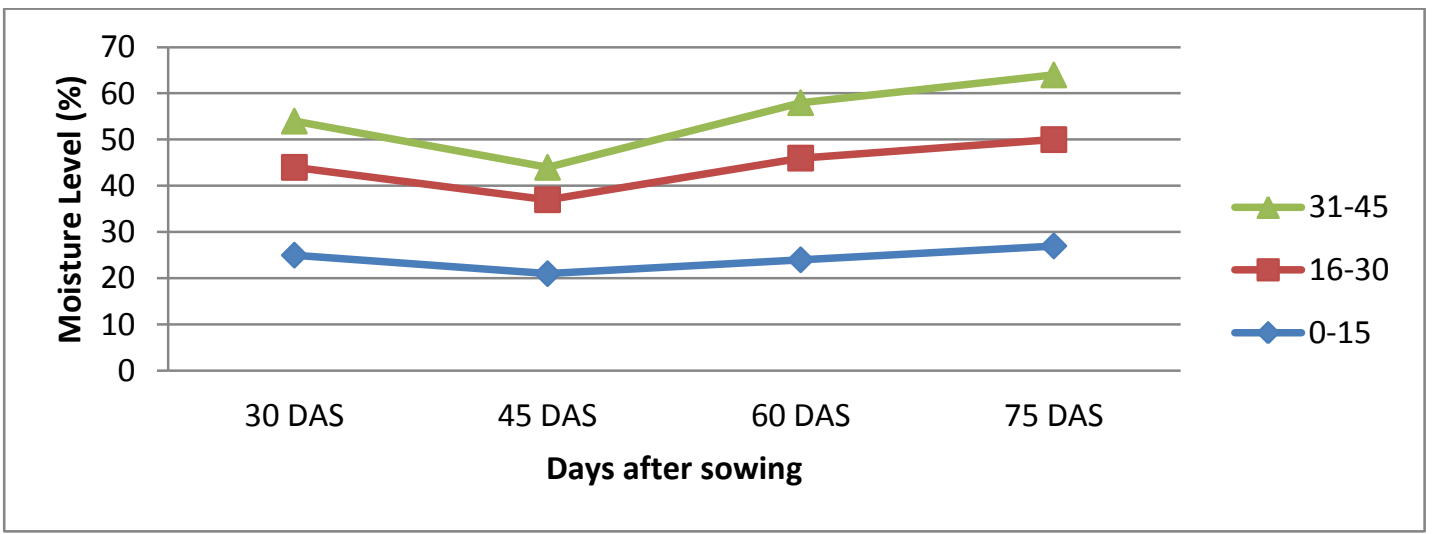

Fig. 1. Moisture Level (\%) at different days after sowing (DAS) and soil depth (cm)

Table 1. Initial soil analysis values of the experimental plot

\begin{tabular}{lcccccc}
\hline $\begin{array}{l}\text { Soil } \\
\text { Parameters }\end{array}$ & $\mathrm{pH}$ & $\begin{array}{c}\text { Organic } \\
\text { matter (\%) }\end{array}$ & $\begin{array}{c}\text { Total } \mathrm{N} \\
(\%)\end{array}$ & $\begin{array}{c}\mathrm{K} \text { (meq. } / 100 \mathrm{~g} \\
\text { soil })\end{array}$ & $\mathrm{P}(\mu \mathrm{g} / \mathrm{g})$ & $\mathrm{S}(\mu \mathrm{g} / \mathrm{g})$ \\
\cline { 2 - 7 } & 6.6 & 1.09 & .058 & 0.10 & 22.4 & 8.0 \\
\hline $\begin{array}{l}\text { Critical } \\
\text { level }\end{array}$ & - & - & - & 0.12 & 10 & 10 \\
\hline
\end{tabular}


Ahmed et al.

Table 2. Different growth parameters of Potato as effected by sowing date and variety

\begin{tabular}{lccccccc}
\hline Sowing date & Variety & \multicolumn{3}{c}{ 45 DAP } & \multicolumn{3}{c}{ 60 DAP } \\
\cline { 3 - 8 } & & $\begin{array}{c}\text { Plant } \\
\text { height } \\
(\mathrm{cm})\end{array}$ & $\begin{array}{c}\text { leaf area } \\
\left(\mathrm{cm}^{2} / \text { plant }\right)\end{array}$ & $\begin{array}{c}\text { Dry } \\
\text { matter } \\
(\%)\end{array}$ & $\begin{array}{c}\text { Plant } \\
\text { height } \\
(\mathrm{cm})\end{array}$ & $\begin{array}{c}\text { Leaf Area } \\
\left(\mathrm{cm}^{2} / \text { plant }\right)\end{array}$ & $\begin{array}{c}\text { Dry } \\
\text { matter } \\
(\%)\end{array}$ \\
\hline November 20 & BARI Alu-35 & 34.5 & 120 & 16.30 & 48.65 & 341 & 20.30 \\
& BARI Alu-40 & 26.3 & 136 & 13.31 & 34.35 & 463 & 19.04 \\
& BARI Alu-41 & 35.3 & 231 & 12.83 & 44.10 & 314 & 21.54 \\
\hline December 5 & BARI Alu-35 & 28.7 & 250 & 9.60 & 42.12 & 572 & 19.62 \\
& BARI Alu-40 & 40.9 & 200 & 14.21 & 41.25 & 600 & 17.34 \\
& BARI Alu-41 & 32.3 & 190 & 12.0 & 42.45 & 585 & 18.42 \\
\hline December 20 & BARI Alu-35 & 25.7 & 237 & 9.20 & 47.32 & 563 & 18.61 \\
& BARI Alu-40 & 33.1 & 190 & 11.50 & 56.68 & 490 & 17.51 \\
& BARI Alu-41 & 34.3 & 240 & 14.63 & 46.21 & 320 & 21.30 \\
\hline CV $(\%)$ & & 7.63 & 20.24 & 7.50 & 7.58 & 16.37 & 6.85 \\
LSD(0.05) & & 1.91 & 3.54 & 2.34 & 2.64 & NS & 3.51 \\
\hline
\end{tabular}

Table 3. Effect of different sowing date on growth and yield of Different potato varieties

\begin{tabular}{llcccccc}
\hline Sowing date & Variety & $\begin{array}{c}\text { Plant } \\
\text { height } \\
(\mathrm{cm})\end{array}$ & $\begin{array}{c}\text { leaf area } \\
\left(\mathrm{cm}^{2}\right) \\
\text { /plant }\end{array}$ & $\begin{array}{c}\text { Tuber } \\
\text { no/hill }\end{array}$ & $\begin{array}{c}\text { Tuber } \\
\text { weight/ } \\
\text { hill }(\mathrm{g})\end{array}$ & $\begin{array}{c}\text { Dry } \\
\text { matter } \\
(\%)\end{array}$ & $\begin{array}{c}\text { Tuber } \\
\text { Yield } \\
(\mathrm{t} / \mathrm{ha})\end{array}$ \\
\hline November 20 & BARI Alu-35 & 72.5 & 372 & 9 & 255.8 & 19.0 & 28.65 \\
& BARI Alu-40 & 76.3 & 536 & 8 & 675.1 & 20.3 & 34.35 \\
& BARI Alu-41 & 85.3 & 530 & 9 & 563.1 & 21.4 & 35.38 \\
\hline December 5 & BARI Alu-35 & 78.7 & 450 & 12 & 871.5 & 19.5 & 42.12 \\
& BARI Alu-40 & 70.9 & 400 & 9 & 864.5 & 19.3 & 31.25 \\
& BARI Alu-41 & 92.3 & 425 & 13 & 887.7 & 20.4 & 38.28 \\
\hline December 20 & BARI Alu-35 & 65.7 & 537 & 8 & 659.8 & 18.5 & 27.32 \\
& BARI Alu-40 & 73.1 & 490 & 7 & 543.2 & 22.4 & 25.68 \\
& BARI Alu-41 & 60.1 & 360 & 9 & 602.7 & 20.3 & 24.38 \\
\hline CV (\%) & & 5.63 & 20.24 & 8.97 & 7.85 & 6.76 & 7.58 \\
LSD (0.05) & & 2.45 & NS & 4.27 & 5.62 & 2.31 & 4.28 \\
\hline
\end{tabular}

\section{Conclusion}

It can be concluded from the findings on different parameters of yield of potato var. BARI Alu35 and BARI Alu- 41 that sowing time at December (first decade) is the optimum for obtaining better yield of potato but reasonable yield could be possible upto December20.

\section{Acknowledgement}

Author is thankful to Tuber Crop Research Centre (TCRC), Bangladesh Agricultural Research Institute for suggestions and supplying the seeds in time. 
Gowth and Yield Performance of Potato Varieties Under Different Planting Dates

\section{References}

Begum, A. A., M. N. Islam, S. S. Kakon, M. A. H. M. Kamal, M. A. Aziz, and S. K. Paul. 2015.

Effect of sowing date of Sweet corn on potato + sweet corn intercropping system. Bangladesh Agron. J. 18(2): 15-21.

Begum, F., B. C. Kundu, and M. I. Hossain. 2015. Physiological analysis of growth and yield of potato in relation to planting date. J. Bangladesh Acad.Sci. 39, (1): 45-51.

Chakraborty, S., N. Chakraborty and A. Datta. 2010. Increased nutritive value of transgenic potato by expressing a nonallergenic seed albumin gene from maranthus hypochondriacus. Proc. Natl. Acad. Sci.USA, 97: 3724-3729.

Dallacosta, L., G. Dellevedove, G. Gianquinto., R. Giovanardi, and A. Peressotti.1997. Yield, water use efficiency and nitrogen uptake in potato: influence of drought stress. Potato Res. 40: 19-34.

Haas, B. J., S. Kamoun, M. C. Zody, R. H. Y. Jiang, R. E. Handsaker, L. M. Cano, M. Grabherr, C. D. Kodira, S. Raffaele and T. Torto-Alalibo. 2009. Genome sequence and analysis of the Irish potato famine pathogen Phytophthora infestans. Nature, 461: 393-398.

Hossain, M. M., M. M. Rahman, A. H. M. R. H. Chowdhury, B. Ahmed and M.A. Salam. 2010. Photosynthetic potential and grain growth study in different boro rice cultivars. Int. J. Sustain. Agril. Technol. 6(9): 26-32.

Li, P. H. 1985. Potato Physiology. Academic Press Inc. (USA):1-602.

Shaheenuzzamn, M., R. R. Saha, B. Ahmed, J.Rahman and M. Selim. 2015. Green cob and fodder yield of sweet corn as influenced by sowing time in the hilly region. Bangladesh J. Agril. Res. 40(1): 61-69.

Sofield, K., L. T Evans, M. G. Cook and F. Wardlaw. 1977. Factors influencing the rate and duration of grain filling in wheat. Aust. J. Plant. Physiol. 4: 785-79. 